Senka Hočevar Ciuha

\title{
IZZIVI PRIHODNOSTI - HOLISTIČNA STRATEGIJA IN SINERGIJA VEDNOSTI
}

\section{POVZETEK}

Vsak dan vidimo, kako nepredvidljiva je prihodnost. Sodobni sociologi današnje družbeno stanje imenujejo »obdobje tekoče moderne«, »družba konca gotovosti«, »svet brez, ligatur«. Kakor je to čas socialnih in ekonomskih bifurkacij, je to tudi čas priložnosti. Prispevek orisuje družbeno ozadje v kategorijah moderne in postmoderne, posledice katerega so vidne v strukturi šolstva in sodobni človekovi osebnosti. V neskladju med dialektiko kot pragmatiko narativne vednosti in didaktiko znanstvene vednosti, ki je legitimizirana skozi institucionalno mrežo jezikovnih iger, leži vzrok viharja kaotičnih ekonomskosocialnih razmer ter človeka pred zlomom moralnih vrednot. Na holistični strategiji, ki človeka v prvi vrsti razume kot celostno bitje, smo utemeljili vseživljenjsko učenje in izobraževanje kot korekturni model trenutneтu izobraževalnemu sistemu.

Ključne besede: moderna, postmoderna, merkantilizacija vednosti, jezikovne igre, legitimizacija, dialektika, pragmatika narativne vednosti - savoir, didaktika, pragmatika znanstvene vednosti, substativno racionalno, brezposelnost, industrializacija prostega časa, vseživljenjsko izobraževanje in učenje, intrinzična motivacija, holistična strategija, izkustveno izobraževanje, multipla inteligenca, ustvarjalni človek

\section{CHALLENGES OF THE FUTURE HOLISTIC STRATEGY AND SYNERGY OF KNOWLEDGE - ABSTRACT}

Everyday we witness uncertain future. Modern sociologists today's social situation name as »liquid modern period «, »end of certainty ", "world without ligatures". As this is a time of social and economic bifurcation, it is also a time of opportunities. The article outlines the social background of modern and postmodern categories, with consequences which are visible in the educational structure of schools and in a psychology of a modern human person. The discrepancy between dialectic of narrative knowledge and didactics as pragmatics of scientific knowledge - which is legitimised through institutional network of language games - lies the cause of storm chaotic economic - social conditions and human moral values breakage. Holistic strategy, which primarly understands a man as an integrated human being, we set up lifelong education and learning as a corrective model of the current educational system and vision for the future.

Keywords: modern, postmodern, merkantilisation of knowledge, language games, legitimisation, dialectic, narrative pragmatics of knowledge - savoir, didactics, pragmatics of scientific knowledge, rational substantial, unemployment, industrialization of leisure time, lifelong education and learning, intrinsic motivation, holistic strategy, experiential education, multiple intelligence, creative man.

\section{MODERNA IN \\ POSTMODERNA - MED STRAHOVI IN PRILOŽNOSTMI}

Živimo na prehodu iz kapitalističnega svetovnega gospodarstva $\mathrm{v}$ drug svetovni sistem ali sisteme. To je čas spopadov in očitno vse hujših neredov ter tistega, $v$ čemer številni vidijo zlom moralnih sistemov. Seveda je to čas, ki bo zahteval dobro mero človeške potrpežljivosti, neupogljive vizije in strukturne ustvarjalnosti. Hkrati se pred našimi očmi odvija revolucija - nepričakovana "poroka« razuma na vrhuncu njegovih zmag in tako dolgo zapostavljene intuicije. Za tankočutnega opazoval- ca je očitno, da problemi, s katerimi se sooča sodobna inteligenca, niso več problemi napredka. Začeli smo govoriti in bomo govorili o spremembi stanja, o preobrazbi: »Zadovoljene radovednosti naj se obrnejo $\mathrm{v}$ svet, povrnejo vero $\mathrm{v}$ svobodo, lucidnost na poti, ki vodi $\mathrm{v}$ svet človeka!« Pomembno je odkriti, do katere mere so ritmi tradicionalnega mišljenja skladni z gibanji sodobnega mišljenja. Sprememba stanja je neločljivo povezana s preobrazbo človekovega uma. To pomeni, da bo učeči ob odkritju različnih realitet (bodisi narativne ali znanstvene vednosti) moral izkušnjo pretvoriti v spoznanje (savoir) ali znanje $\mathrm{z}$ drugega 
(kot spoja razuma in intuicije) zornega kota. Duhovni in znanstveni jezik nista nasprotje drug drugemu, saj je konzumacija duhovnega jezika v znanstvenem rodila največje človeške izume. Elektrika, rentgenski žarki, gibanje Zemlje idr. Če se povrnemo v sedanjost, je modernizem izuril racionalizem, postmodernizem pa z odtegljajem »svetega « prebudil lakoto prav po njem. Šola kot odraz stanja je $\mathrm{v}$ današnji vlogi primerljiva s Platonovo prispodobo o votlini. Režiserji »gledališča senc « bodo popustili pred zavedajočimi se pedagoške odgovornosti.

Vodilne metafore vzpona modernizma so: znanost, racionalnost, opazovanje, razvoj in napredek (Ule, 2000). Posttradicionalni družbeni red - moderna - ruši različne vrste tradicij: rodovne, nacionalne, stanovske, razredne, mistično religiozne. Od ljudi zahteva sprotno in splošno refleksijo lastnega početja, doživljanja in razmišljanja. »Sveto« se v svoji dolgi zgodovini še ni spopadlo s tako velikim izzivom. Izurili smo se v tem, da nas več ne skrbijo reči, ki trmasto presegajo naše moči, pozornost in energijo. Raje se usmerjamo v dosegljivo, v svoje zmožnosti in sposobnosti porabništva (Baumann, 2008) Prav tako pa je za moderno značilno, da vzajemno poveča število življenjskih alternativ. Življenjske možnosti so funkcija priložnosti in globokih socialnih povezav. Priložnosti so možnosti izbire, alternative delovanja, ki so dane $\mathrm{v}$ socialnih strukturah in so vedno specifične kombinacije pravic in dolžnosti. V moderni je cilj več življenjskih možnosti, pri čemer so slednje koordinate, ki določajo smisel priložnosti. Iz tega sledi vprašanje, kako naj se moderni človek reši iz zagate multiplih priložnosti brez jasnih koordinat in definicije smisla (Ule, 2000: 8, 9).

Baumann obdobje moderne imenuje »tekoče« obdobje moderne, izhajajoč iz dejstva, da tekočine ne morejo obdržati svoje oblike. $\mathrm{V}$ tekoči moderni je strategija »carpe diem « - življenje kot priložnost, ki se ponuja in jo mora človek izkoristiti, kolikor se da - odgo- vor na svet, v katerem ni več trajnih vrednot (Baumann, 2008). Dahrendorf vidi rešitev v notranjem kompasu, ki ga posamezniki imajo ali nimajo. Riesman notranji kompas imenuje notranje vodstvo, Kant »Triebfeder «. To je Dahrendorfov »simptom sveta brez ligatur «. Ligature so globoke kulturne vezi, ki ljudi usposabljajo za to, da najdejo smisel v svojih izbirah in jim zaupajo. Moderna je prelom $\mathrm{z}$ ligaturami
Priložnosti so možnosti izbire in $\mathrm{s}$ tem kombinacija pravic in dolžnosti. starih časov, je družbeni, manifestni vidik globljega procesa opuščanja religioznih, mistično-magijskih, organsko celostnih, kvalitativnih pogledov na svet. Tako je v Evropi prišlo do notranje povezave med razvojem racionalnega in delovanja ter ponotranjene etike dela. Zato se je dogodilo odčaranje sveta, raztapljanje religioznih pogledov na svet in je nastala profana kultura (Ule, 2000: 10, 11).

»Postmoderno « stanje je stanje vednosti v najrazvitejših družbah. Sociologi in kritiki označevalec uporabljajo tudi za stanje kulture po transformacijah, ki so vplivale na pravila iger znanosti, literature in umetnosti od konca 19. stoletja dalje, v kolikor znanost - če jo izpostavimo - išče tisto resnično, za kar je dolžna upravičiti svoja pravila igre. O svojem lastnem statusu govori v diskurzu legitimiranja. Merkantilizacija vednosti je učinek postmoderne ideologije, ki svojo legitimnost utemeljuje in izvršuje glede na učinke diskurzov, različnih vrst izjav - didaktičnih sporočil, ki jih imenuje jezikovne igre (Lyotard, 2002). Z legitimiranjem vednosti je neločljivo povezana učinkovitost institucij, ki obvladujejo družbeno vez: tudi te institucije je treba legitimirati. Iz tega izhajajoča delovna hipoteza se glasi: Vednost spreminja status hkrati s tem, ko družbe vstopajo $\mathrm{v}$ tako imenovano postindustrijsko dobo, kulture pa $\mathrm{v}$ tako imenovano postmoderno dobo. V svojem statusu je vednost postala glavna proizvodna sila in kot obče družbeno znanje, »knowledge «, neposredna produktivna 
sila. Slaba novica: občutno se spreminja sestava aktivnega prebivalstva v najrazvitejših državah in pomeni najožje grlo za dežele v razvoju. V svoji obliki informacijskega blaga, ki je nepogrešljivo za proizvodno moč, je vednost postmoderne najpomembnejši dejavnik $\mathrm{v}$ svetovnem tekmovanju za oblast. Nacionalne države se namesto za oblast nad ozemlji (večino-

V postmodernizmu
je vednost najpo-
membnejsi dejav-
nik v svetovnem
tekmovanju za
oblast.
ma) bojujejo za obvladovanje informacij. Ta pojav imenujemo »merkantilizacija vednosti«. Ideologija komunikacijske »transparentnosti« gre vzporedno s komercializacijo vednosti skozi njej imanentni proces legitimiranja kot jezikovne igre. Lyotard (2002: 22) s tem terminom označuje, da morajo vsako izmed različnih kategorij izjav (denotativne, performativne, kognitivne ...) določati pravila, ki specificirajo njihove lastnosti in možno rabo. Denotativne izjave, na primer, so izjave take vrste, pri katerih je bistveno dejstvo, da je pošiljatelj vedno v poziciji vedočega, medtem ko lahko prejemnik pozicijo pošiljatelja le sprejme ali zavrne. Druga vrsta izjav so tako imenovane performativne izjave. Značilno za te je, da je njihov učinek na referenta dosežen že skozi njihovo izjavljanje. Lyotardov primer za performativno izjavo je stavek rektorja ob odprtju univerze. »Univerza je odprta!« je izjava, ki tudi dejansko uresniči odprtje univerze.

Didaktika postmoderne šole vsako kategorijo izjav uporabi kot legitimno metodo za podajanje informacij. V ospredje bomo postavili tri lastnosti jezikovnih iger (Lyotard, 2002):

1. Pravila jezikovnih iger svojega legitimiranja ne nosijo v sebi, temveč so predmet neke izrecne ali neizrecne pogodbe med igralci.

Slaba novica: šola proizvaja igralce jezikovne igre na podlagi neizrecne pogodbe med proizvajalci in igralci.

Ne zadošča nam le teorija komunikacije, da bi razumeli družbena razmerja, temveč potrebu- jemo teorijo iger. Šola kot reproduktivni člen družbenih razmerij $v$ svojem didaktičnem diskurzu razvija prožne mreže jezikovnih iger. $\mathrm{V}$ tem se institucija razlikuje od diskusije; zahteva dodatne omejitve, da bi bile izjave znotraj institucije sprejete kot dopustne. V okviru didaktičnih načel obstajajo stvari, ki jih je treba reči, in tudi načini, kako jih povedati.

2. Brez pravil igra ne obstaja in že minimalna sprememba nekega pravila spremeni naravo igre.

Slaba novica: pravila igre so učencem kot prihodnjim proizvajalcem pravil jezikovne igre zunanja, kar pomeni zanikanje individualizacije v korist standardizacije ne zgolj znanja, temveč tudi zahtevanih sposobnosti za njegovo pridobitev.

Pravila igre so najodločilnejši pogoj za samoregulativen sistem družbe. Vsak problem dinamične analize sistemske samoregulacije je trajno in sistematično povezan s stanjem sistema, obravnavanim kot celota. Proces ali skupek pogojev - kot orodje, izbor kategorije izjav določenih pravil igre - bodisi »prispeva « $\mathrm{k}$ vzdrževanju sistema bodisi je »disfunkcionalen « v tem, da škoduje celovitosti in učinkovitosti sistema. V postmoderni perspektivi subjekt pomeni le malo, vendar ni izoliran, saj je bolj kot kadarkoli prej ujet $\mathrm{v}$ kompleksen in mobilen ustroj komunikacij. Subjekt je postavljen na »vozle « komunikacijskih kroženj, to je mesta, skozi katera tečejo raznovrstna sporočila.

3. Vsaka izjava mora biti obravnavana kot »poteza«, ki se izvede v neki igri. Iz tega sledi, da govoriti pomeni boriti se v smislu igranja.

Slaba novica: postmoderna šola ne spodbuja sistematičnega kritičnega mišljenja, ki ima sposobnost preobrazbe trenutnega stanja in $\mathrm{s}$ tem značaj inovativnosti, temveč spodbuja kritično mišljenje kot nasprotje, ki je imanentno funkciji »govoriti pomeni boriti se $\mathrm{v}$ smislu igranja k kot reprodukcije »utopij « - t. j. mesta nikjer kot drugod. Subjekt na »vozlih « komunikacijskih kroženj, tudi kadar je najbolj za- 
Šola kot institucionalizirani trg igralcev in potrošnikov jezikovnih iger reproducira pravila, ki določajo različne kategorije izjav ter specificirajo njihove lastnosti in možno rabo. Institucionalizacija trga vednosti vedno zahteva omejitve, da bi bile izjave znotraj institucije sprejete kot dopustne. Te omejitve delujejo na diskurzivne moči kot filtri, prekrivajo možne zveze na komunikacijskih mrežah: obstajajo stvari, ki se ne smejo reči. Omejitve dajejo prednost nekaterim razredom izjav. A vedno obstajajo stvari, ki jih je treba reči, in načini, kako jih povedati (Lyotard, 2002: 22, 34). Na tem mestu dajemo prednost didaktiki kot najučinkovitejšemu orodju pragmatike znanstvene vednosti.

postavljen, ni brez moči nad sporočili, ki ga postavljajo bodisi na mesto pošiljatelja bodisi na mesto prejemnika. Njegova premostitev »poteza« - glede na učinke jezikovnih iger je dopustna $\mathrm{v}$ določenih mejah in se celo spodbuja z regulacijami, ki se jim sistem posveča $\mathrm{z}$ namenom, da bi izboljšal svoje dosežke.

\section{DIALEKTIKA KOT PRAGMA- TIČNO ORODJE NARATIVNE VEDNOSTI, DIDAKTIKA KOT PRAGMATIČNO ORODIE ZNAN- STVENE VEDNOSTI}

\section{Dialektika kot pragmatično orodje narativne vednosti}

S terminom vednost - »savoir « - ne označujemo zgolj skupka denotativnih izjav (t. j. izjav, ki imajo kognitivno vrednost), v njem so tudi predstave o znati storiti - »savoir faire«, znati živeti - »savoir vivre« in znati poslušati »savoir écouter «. Gre torej za kompetenco, ki presega določilo in uporabo edinega kriterija resnice. Narativna vednost ni v kompetenci za določeno vrsto izjav, denimo kognitivnih, pri čemer bi bile vse druge izključene. Nasprotno, omogoča »dobre« izvedbe glede več diskurzivnih objektov: spoznati, odločiti, oceniti, preoblikovati ipd. Od tod izhaja ena izmed njenih poglavitnih potez: sovpada z nekim širokim formiranjem kompetenc, je edinstvena forma, utelešena v subjektu, ki ga sestavljajo različne vrste kompetenc, ki ga konstituirajo (Lyotard, 2002: 36). Te konstitutivne kompetence so razvojne tipologije učečega se odra- slega in so sinergija starostne, spolne, rasne kategorije kot tudi kognitivnega, čustvenega, moralnega in estetskega razvoja subjekta.

\section{Didaktika kot pragmatično orodje znanstvene vednosti}

Pragmatika znanstvene vednosti v postmoderni trči ob problematičnost pravila adekvatnosti: To, kar rečem, je resnično, ker to dokažem; toda kaj dokazuje, da je moj dokaz resničen? Znanstvena rešitev te težave je v upoštevanju določenega dvojnega pravila:

1. Didaktično ali retorično: kolikor to lahko dokažem, je dovoljeno misliti, da je resničnost takšna, kot rečem jaz.

2. Metafizično pravilo: učitelj ne more ponuditi več protislovnih ali šibkih dokazov.

Dvojnost pravila omogoča horizont konsenza. Resnica izjave in kompetenca izjavljavca sta podvrženi soglasju skupnosti enakopravnih po kompetenci. Zato je treba formirati enakopravne posameznike, kar je naloga didaktike. Njena prva predpostavka je, da prejemnik (učenec) ne ve tistega, kar ve pošiljatelj (učitelj). Druga predpostavka je, da se lahko tega nauči in postane strokovnjak, ki ima enako kompetenco kot njegov učitelj. Ta dvojna zahteva predpostavlja tretjo: da obstajajo izjave, zaradi katerih se izmenjava argumentov in podajanje dokazov, ki tvorijo pragmatiko raziskovanja, upoštevata kot zadostna, in jih zato lahko prenašamo kot takšne, kakršne so, kot nesporne resnice o poučevanju. (Lyotard, 2002: 45) Primerjava znanstvene pragmatike s pragmatiko narativne vednosti: 
1. Znanstvena vednost zahteva izoliranje neke jezikovne igre in izključitev drugih. Kriterij sprejemljivosti neke izjave je vrednost resnice.

2. Kombinacija jezikovnih iger tvori družbeno vez ter je neposredni in skupni del narativne vednosti. Znanstvena vednost je ločena od drugih jezikovnih iger, je njen posredni del, ker postane poklic in omogoči obstoj institucije. V sodobnih družbah se jezikovne igre regrupirajo $\mathrm{v}$ obliki institucij, ki jih vodijo usposobljeni strokovnjaki. Odnos med družbo in vednostjo se eksteriorizira. Pojavi se nov problem, in sicer problem razmerja med znanstveno institucijo in družbo. Ali se problem lahko reši s pomočjo didaktike na podlagi predpostavke, da vsak družbeni atom pridobi znanstveno kompetenco? Odgovor bomo v nadaljevanju skušali najti v Wallersteinovi opredelitvi »substativne racionalnosti

3. V osrčju igre raziskovanja se zahtevana kompetenca nanaša na mesto izjavljavca. $\mathrm{Tu}$ ni potrebno, kot $\mathrm{v}$ narativnem (»savoir «), biti tisto, kar pravi vednost, da smo. Wallerstein v delu Utopistike ali izbira zgodovinskih možnosti 21. stoletja (1999) v pojmovno-diskurzivni ločitvi med »utopijo« in »utopistiko« vpelje dva načina empiričnega preučevanja družbene realnosti. Utopije imajo religiozne funkcije, so gojišča iluzij in razočaranj; lahko pa so uporabljene tudi kot opravičilo za hude krize. Utopistika pa je po Wallersteinu ocena zgodovinskih možnosti, je trezno, racionalno in realistično ovrednotenje človeških družbenih sistemov, njihovih omejitev in področij, ki so odprta za človeško ustvarjalnost - »surplus savoir faire«. To ni obraz popolne prihodnosti, temveč alternativne prihodnosti. Iz tega sledi, da je utopistika usklajevanje tistega, kar se naučimo od znanosti, morale in politike (sinergije znanstvene in narativne vednosti) o tem, kaj naj bi bili naši splošni, ne podrejeni cilji, ki jih imenujemo sredstva. Za pravo izbiro splošnih ciljev je treba v posamezniku razviti substativno racionalnost, ki mu omogoča izbiro ciljev na podlagi merila vrednostnih postulatov kot uspešnega odgovora na lastno vizijo in potrebe družbene realnosti. Kje vstopi znanost? Kako »pomaga« pri sprejemanju moralnih in političnih odločitev? Kakor smo trdili za znanstvenost, velja tudi za narativno vednost (»savoir écouter, savoir vivre, savoir, savoir faire «), da je za nemoteno delovanje sistema in njegovega postopka za sprejemanje odločitev potrebna podpora širše skupine ljudi - legitimnost. V tem pomenu je legitimnost izid dolgotrajnega procesa dialektike jezikovnih iger in njihovih diskurzivnih učinkov, da prepričamo tiste, ki jim gre kratkoročno slabo, da jim bo šlo nekoč, dolgoročno, bolje, zaradi strukture sistema. Izguba legitimnosti je dejavnik za sistemsko krizo.

Vsako spremembo družbenega reda moramo legitimizirati s sklicevanjem na avtoriteto (t. j. izjavljavec resnice), najuspešneje (v dolgoročni perspektivi) z racionalnimi argumenti, ki se porajajo $\mathrm{v}$ znanstvenem diskurzu, njihovo veljavnost pa potrjujemo na temeljih sprejetega znanstvenega znanja, ki je vprašanje veljavnosti našega kolektivnega znanja oziroma tistega znanja, ki sestavlja našo substativno racionalnost. To pa zahteva ponovni razmislek o strukturah znanja kot vrednostnih in vsebinskih postulatih jezikovnih iger. V iskanju substativne racionalnosti dobre družbe je na naši strani človeška ustvarjalnost (Wallerstein, 1999). Če hočemo zgrabiti svojo priložnost, kar je naša moralna in politična dolžnost, moramo najprej dognati, kaj ta priložnost je in iz česa je sestavljena. 


\section{UTOPISTIKA ALI UTOPIJA IZOBRAŽEVALNEGA SISTEMA NA PRIMERU BREZPOSELNOSTI IN PROSTEGA ČASA}

Citat iz Sokratove pedagoške prisege:

Kot učitelj in vzgojitelj se obvezujem:

- otroku omogočiti pridobitev izkušenj o svetu, kakršen je v resnici, vendar ga ne podrediti svetu, kakršen je;

- ponuditi mu vizijo boljšega sveta in ga prepričati, da jo je mogoče ustvariti;

- kolikor je mogoče spoznati zakonitosti njegovega razvoja, ga postaviti na dobre temelje in mu omogočiti sprejetje teh zakonitosti;

- pridobiti otrokovo potrditev za vse, s čimer vplivam na njegovo osebnost, enako kot bi postopal nasproti odraslemu (von Henting, 1997: 258).

Če bi v diskurzu Sokratovih pedagoških načel vzeli v precep današnji izobraževalni sistem, bi njegove obveze označili za utopije. Toda prav verjetje v Sokratova pedagoška načela nas žene in krepi v volji, da lahko ustvarjamo presežne vrednosti, krmarimo v ravnotežju med osebnim navdihom in družbenimi zahtevami. Kadar se lomi in zlomi, zgradimo znova. To nas uči zgodovina človeštva, ki je tudi v času družbenih bifurkacij potrpežljiva in trpežna. To nas uči Wallersteinova utopistika družbene realnosti.
Vztrajamo na robu mejnega med spoznanjem in mistiko v raziskovanju središča problema. Vztrajamo na sožitju delotvornega in plodotvornega. Ko je človek izumil tisk, da bi se izognil obsežnemu prepisovanju, si ni predstavljal, da bo to odkritje nekega dne vse ljudi prisililo k učenju pisanja in branja. V 20. in 21. stoletju mehanična konstrukcija tehnološke izume naredi za orodje, ki ga kopičimo in standardiziramo na račun individualizacije, variacije, estetike, smelosti, kontinuitete, avtonomije in solidarnosti. Nekega dne, ko se potrošnja zadovolji, začnejo izumirati gozdovi, lomi se obrambni mehanizem našega telesa, nimamo več zaupanja $\mathrm{v}$ javno mnenje. Zdi se, kot da vse več predmetov in aparatov zahteva našo pozornost - torej akumulacijo. Ker je tehnologizacija delotvorna tudi $\mathrm{v}$ gospodarstvu, se je zmanjšal obseg neposrednega človeškega dela. »Druga industrijska revolucija « je znanje izenačila $\mathrm{z}$ akumulacijo in akceleracijo informacij, posledice pa niso tako nedolžne, kot se zdi na prvi pogled. Omenimo jih le nekaj, ki bodisi posredno bodisi neposredno krojijo življenja sodobnega človeka: razlikovanje napačnega od pravilnega mišljenja, ki linearno meri uspeh;

- težnja k »perfekcionizmu«, ki je posledica informacijske birokratizacije;

- poudarjanje eksaktnosti in univerzalnosti znanstvenih spoznanj, ki podpira težnjo ljudi, da razmišljanje podredijo znanju.

Brezposelnost je tisti fenomen, $\mathrm{v}$ katerem družbene spremembe postajajo vidne. Kaže

Brezposelnost danes ni posledica umanjkanja dela. Ideologija najnovejšega fenomena brezposelnosti je povezana $\mathrm{z}$ neizogibno družbeno transformacijo, ko se soočamo s koncem družbe napredka kot napredka samega po sebi. Človek, neoborožen s pravimi vrednotami narativne vednosti (kot posledica njenega podrejanja znanstveni vednosti, ne pa medsebojnem oplajanju), je obupan in slep za svet priložnosti. Vzrok za brezposelnost ni v dejstvu, da smo med šolanjem osvojili premalo informacij, t. i. znanja. Čemu potem vsaj 12-letno šolanje? Starši otrokom zagotavljajo, da jim uspeh in šolanje ponujata dobro življenje. A jim ne zagotavljata razumevanja življenja, življenja, za katerega se morajo naučiti prevzeti odgovornost sami. Za čas, ko družbeni varnostni mehanizmi odpovejo, ko se v vrtincu jezikovnih iger in njihove legitimizacije subjekt lomi sočasno z zlomom moralnih vrednot. Nasproti njemu stoji ustvarjalni človek, ki v sebi nosi neizčrpen potencial. 
nam urgentnost sprememb, tudi sprememb strukture izobraževalnega sistema, kjer ne gre za posamičen ukrep, temveč je treba na novo razmisliti o nalogi šole in nujnosti vseživljenjskega učenja kot konstruktivnega elementa družbe, ki svoje cilje podreja humanim in kulturnim vrednotam vsakega človeka. Če nekateri dvomijo o takšni družbi, predlagamo pregled zgodovine vladanja indijskega princa Ašoke iz časa 304-232 pr. n. št.

$\mathrm{Z}$ »drugo industrijsko revolucijo« pa je neločljivo povezan še en ključni sodobni fenomen, t. i. prosti čas. Pedagogika prostega časa je nastala z namenom, da bi mlade ljudi obvarovala pred vplivom industrije prostega časa, drog in kriminala. Toda že sama delitev na delovni in prosti čas je sporna, saj potencira razumevanje prostega časa kot časa, v katerem ne delamo, ne ustvarjamo. $\mathrm{V}$ prid industriji prostega časa je delovni čas produktiven, prosti čas pa je namenjen zadovoljevanju umetnih potreb, ki jih ustvarja omenjena industrija. Nekateri celo trdijo, da je vznik sodobnega kapitalizma posledica omenjene delitve. Prosti čas bi moral biti plodotvorni čas in delovni čas delotvorni. Med obema pa bi morala obstajati neprekinjena sinergija, ki je zagotovilo kakovosti življenja. Motivacija in tako naravna osebnostna struktura bi morali biti cilj vzgojno-izobraževalnega momenta šolske politike. Če je šola kraj, v katerem se živi, potem je njena naloga razvoj celovitega človeka. To pa zahteva »holistično učenje«, ki ni zgolj domena didaktike (kot orodja znanstvene vednosti), temveč učenje in pridobivanje izkušenj prek občih značilnosti družbenega življenja (prek izkušenj in delovanja v okvirih dialektike narativne vednosti).

$\mathrm{S} »$ holističnim učenjem « bi nadoknadili naslednje izgube:

- izgubo čutne izkušnje v korist teorij;

- izgubo sinergetičnega mišljenja kot iskanja pomena v korist funkcionalnosti;

- izgubo odgovornosti v korist pomembnosti posameznih področij;
- izgubo razumevanja v korist podhranjenega znanja;

- izgubo neposrednosti v korist »medijev« (von Henting, 1997: 225).

Nadoknaditi omenjene izgube ne bi smela biti domena pedagogike prostega časa, temveč šolskega kurikula. Če se šola osredotoči zgolj na svoje učne vsebine, otroci pa čas zunaj šole doživljajo kot njihovo nasprotje, to ne odpira poti k razvoju celovitega človeka.

V osebnostni strukturi odraščajočega takšno doživljanje šolske in nešolske realnosti spodbuja dualistično mišljenje (kot nasprotje holističnega), ki vsako situacijo razume kot izbiro »aliali« (Juul, 2008: 61). Ali naj bo zvest samemu sebi, naj torej spoštuje svojo integriteto, osebne meje in potrebe, ali naj se odreče svojim željam zato, da bi ohranil razmerje, se torej podredil zunanjim zahtevam iz strahu pred vsemogočnostjo izjavljavca in tvorca jezikovne igre. Izbira »tudi-tudi « je uspešna, kolikor je produkt holističnega mišljenja, ki je tako tudi povezano neposredno s sposobnostjo odraščajočega, da se osebno izrazi (produkt šolanja), posredno pa s kulturnim vrednostnim postulatom.

Za zaključek in prehod k nadaljnjemu razmišljanju bi navedli nove citate Sokratove zaprisege:

- v skladu s svojimi močmi bom poskrbel, da prihajajoči naraščaj doživi svet kot takšen, v kakršnem je vredno živeti in v katerem podedovana bremena in težave ne pritiskajo na njegove lastne ideje in možnosti;

- javno bom obrazložil svoja verjetja in dela, izpostavil se bom kritiki - posebno kritiki tistih, ki bodo prizadeti, kot tudi kritiki strokovnjakov, svoje predpostavke bom dosledno preverjal (von Henting, 1997: 259).

\section{VSEŽIVLJENISKO UČENJE - HOLISTIĆNA STRATEGIJA}

Intrinzična motivacija je pri posamezniku pogojena $\mathrm{z}$ njegovim interesom za problem, stvar, središče interesnega predmeta samega. Intrinzično motivirani posameznik je bolj 
osredotočen na pot za dosego cilja kot cilj sam. Reševanje problemov vidi kot izziv. Visoka stopnja delovne motiviranosti je posledica intrinzične motivacije, ki je tudi trajnejša od ekstrinzične. Pri slednji gre posamezniku za zunanje razloge, ki nimajo s stvarjo samo nič skupnega: za denar, slavo, družbeni status, politično moč (Makarovič, 2003: 124).

Naloga šole je, da razvojno preobrazi ekstrinzično motivacijo v intrinzično. Takšna preobrazba zahteva učljivost posebne vrste, ki ni zgolj kognitivne narave. Ne gre namreč za znanje, temveč za oblikovanje čustvene inteligence. Posameznik, ki mu je šola privzgojila ljubezen do spoznanja (»savoir faire«) in znanja, ki je »ljubezen« do odkrivanja neznanega, se bo izobraževal vse življenje. Intrinzično motivirani je vznemirjen ob bisociativnem mišljenju - v nasprotju $\mathrm{z}$ asociativnim, ki disparatnost komponent, ki se $\mathrm{v}$ človeški zavesti povežejo med seboj, strne $\mathrm{v}$ enovitost povezave (Koestler, 1964: 35). Prvi pogoj za bisociacije pa je diskurzivna racionalnost (funkcija leve možganske hemisfere, ki je povezana z govorom in delom kot oblikama človekovega sistematičnega in načrtnega obvladovanja zunanjega sveta), katere značilnost je algoritmičnost, postopno izvajanje sklepov iz danih premis: če $\mathrm{A}$, potem $\mathrm{B}$, če $\mathrm{B}$, potem $\mathrm{C}$ itd. Takšno postopno sklepanje poteka $\mathrm{v}$ času, podobno kot poteka $\mathrm{v}$ času govorjenje. Njegovo izhodišče je analitičnost: vedno vzamemo za izhodišče en sam element, izvedemo iz njega drugega, nato tretjega.

Gardner v Frames of Mind (1983) postavi trditev, da obstaja širok spekter multiplih inteligenc, vključujoč sedem glavnih kategorij: lingvistično, glasbeno, logično-matematično, prostorsko, telesno-kinestetično ter medosebno in intraosebno inteligenco. Te osebne inteligence vključujejo vodenje, sposobnost negovanja medosebnih razmerij in prijateljstva, sposobnost reševanja konfliktov ter socialne analize (t. j. kompetence, ki jih razvijemo z narativno vednostjo). Različne naloge zahte- vajo različne sposobnosti. S senzibilizacijo do drugih in prepoznavanjem lastnih moči in šibkosti v različnosti inteligenc se mentorji lahko naučijo prepoznati, kdaj ne zadovoljujejo potreb učečega ali kdaj medosebni odnosi niso učinkoviti. Vseživljenjsko izobraževanje (odslej kratica VŽI) in vseživljenjsko učenje (odslej kratica VŽU) lahko definiramo kot kontinuiran proces evalvacije izkušenj. Pojma izkustveno
Vseživljenjsko učenje je kontinuiran proces evalvacije izkušenj. izobraževanje (»experiential education«) in učenje na osnovi izkušenj (»experience based learning «) se uporabljata izmenjujoče. Izkustveno izobraževanje je definirano kot proces, skozi katerega učeči gradi znanje, spretnosti ter spoznanja iz neposrednih izkušenj. Po drugi strani pa je izkustveno učenje (»experiential learning «) posledica sprememb v osebnostnih sodbah, čustvih, spoznanjih ali spretnostih, ki so tipične za posamezno osebo in njeno življenje (Grealy, Hall-Ellis, 2009).

Holistična strategija VŽI in VŽU združuje narativno in znanstveno vednost ter celosten pogled na specifičnost odraslega kot učečega. (Honey, P., Mumford, A., 2000)

Slika: Honeyjev in Mumfordov model učnih stilov (»learning styles»)

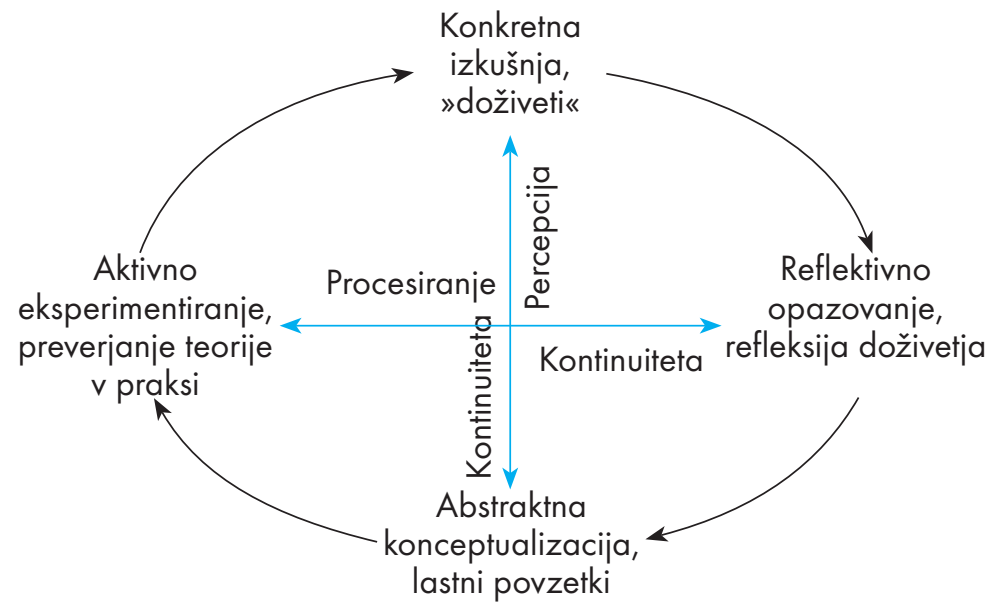


Večje in pestrejše, kot je število izkušenj, doživetvenih refleksij ter preverjanj teorij v praksi, kvalitetnejša in bolj perceptivna je abstraktna konceptualizacija kot podlaga za aktivno eksperimentiranje in selektivnost ter integracijo pridobljenih izkušenj za uspešno cikličnost VŽU in VŽI.

\section{lzkustveno učenje teži $k$ pridobivanju kompleksnih znanj.}

Pri izkustvenem učenju obstaja težnja učečega po pridobivanju kompleksnih znanj. Potreba po znanju izhaja iz konkretnega problema (Krajnc, 1979). Za razrešitev problema ni dovolj samo znanje ene discipline, ampak je potrebna kombinacija znanj, »interdisciplinarnost $\ll, \quad »$ multidisciplinarnost $\ll$ in »transdisciplinarnost «. Interdisciplinarno kaže na spekter spoznanj integrativnih dejavnosti, medtem ko se multidisciplinarno nanaša na pristope, ki prinašajo različna izhodišča za študijski predmet. Po drugi strani pa transdisciplinarni pristop proizvaja prehodnost teorij, ki presegajo posamičnost posameznih znanstvenih disciplin. Didaktika VŽI kot pragmatika znanstvene vednosti bi $\mathrm{v} \gg$ družbi konca gotovosti« promptno vznikajočim potrebam morala vgrajevati znanstvena spoznanja ne zgolj v gospodarsko rast, temveč v prevrednotenje človeških vrednot v korist »ekolizacije« in humanizacije boleče družbene transformacije. Slednje bi pomenilo medsebojno oplajanje človeškega in naravnega kapitala, ne pa podrejanje enega ali drugega $\mathrm{v}$ izčrpavajočo korist gospodarstva. Osvojiti in ponotranjiti bomo morali načelo »manj je več«. Pogoj za gospodarsko rast je trošenje (industrializacija prostega časa); torej kaj če nehamo trošiti? Anketa prebivalcev EU (vir: www.neweconomics.org) o zadovoljstvu in trošenju je pokazala, da med njima ni povezave. Iz tega izhaja pomembna ugotovitev: če bomo trošili manj, ne bomo manj srečni in zadovoljni.

V EU potekajo intenzivne razprave o strategiji Unije do leta 2020. Eden od stebrov te strategije so zelena rast in zelena delovna mesta.
Kako smo na to pripravljeni v Sloveniji? V Strategiji vseživljenjskosti učenja v Sloveniji (ur. Jelenc, 2009) je v ciljih strategije med drugim zapisano:

- $\mathrm{v}$ nacionalni politiki ter $\mathrm{v}$ teoriji in praksi vzgoje in izobraževanja $v$ Sloveniji doseči integracijo vseh področij vzgoje in izobraževanja v koherenten sistem, ki bo zagotavljal enakovredne in enakopravne možnosti za razvijanje in udejanjanje različnih zvrsti, oblik, vsebin in namenov izobraževanja in učenja;

- pospešiti razvijanje »učeče se družbe « in »družbe, ki temelji na znanju « ter »družbe mislečih « kot nujne evolucijske nadgradnje;

- spodbujati in omogočati učenje na vseh življenjskih področjih in področjih dejavnosti. To naj z ustrezni instrumenti omogoči celostna politika, ki mora povezovati gospodarski interes z družbenimi in kulturnimi cilji.

- Za uspešno uresničevanje navedenih ciljev strategije morata biti izpolnjena vsaj dva pogoja:

1. da gre za sistemsko uresničitev, ki zagotavlja kontinuiteto izobraževanja, komplementarnost VŽI in VŽU $\mathrm{Z}$ vsemi formalnimi ter neformalnimi oblikami izobraževanja od predšolskih institucij naprej;

2. razumevanje odraslega kot samostojnega, materialno, socialno in psihološko neodvisnega človeka (Krajnc, 1979: 39).

Razumevanje odraslega kot samostojnega, materialno, socialno in psihološko neodvisnega človeka je celostno razumevanje odraslega. Njegova individualnost je izražena skozi raznolikost razvojnih tipologij, ki so kategorizirane s starostno, rasno, spolno in religiozno pripadnostjo ter kognitivnim, čustvenim, moralnim in estetskim razvojem. Za uspešno učenje odraslega mora mentor poznati in razumeti sinergijo med razvojnostjo življenjskega cikla, inteligenco, kognitivnim razvojem, čustveno inteligenco, spolom, moralnim, estetskim in duhovnim razvojem ter rasno identiteto. Pri tem se mora mentor izolirati od stigmatiziranja, saj 
nasprotno negira celostno identiteto odraslega, ki je rezultat spoja socialne in osebne identitete. Temeljna naloga osebne identitete je lovljenje ravnotežja med identifikacijami z družbo, ki jih ponuja socialna identiteta, in diferenciacijami od referenčnih skupin in družbenih pričakovanj, ki jih ponuja osebna identiteta (Ule, 2000). Stigmatizacija je pogojena $z$ vzvodi ideološko-družbenih vrednostnih mehanizmov, neupoštevanjem posebnosti življenjskega cikla posameznika (negiranje individualnosti) ter zanikanjem obstoja multiple inteligence (lahko kot posledica poudarjanja univerzalnosti znanja, evalvacijske linearnosti in izobrazbene standardizacije). Pospeševanje učenja - pomoč odraslemu, da najde smisel in deluje glede na socialno, delovno in politično-družbeno okolje in čas, v katerem živi - je pomembna, entuziastična in temeljita dejavnost, tako za mentorje kot za učeče. Je tudi kompleksna psihosocialna drama, kjer so individualne osebnosti vpletene v vsebinske forme za izobraževalne namene v okvire predpostavljenega socialnega ozračja, ki posega $v$ naravo in obliko učenja.

\section{ZAKLJUČEK}

Februarja letos (vir: www.neweconomics.org) je bila objavljena študija o skrajšanju delavnika na 21 ur na teden, ki je posledica reševanja ekonomske, socialne in okoljske krize. Raziskovalci v študiji trdijo, da je to - v perspektivi trajnostnega razvoja - prej pozitivna priložnost kot nevarnost. Omejitev gospodarske rasti in ob tem preprečitev socialnega zloma, brezposelnosti in neenakomerne porazdelitve bogastva se lahko omili s prerazporeditvijo dela. Manj dela, manj zaslužka, manj trošenja. In česa več? Časa. Kakor je na prvi pogled vabljivo, je to zahteven poseg $\mathrm{v}$ življenje sodobnega človeka. V 70. letih 20. stoletja so na Švedskem izvedli eksperiment, v katerem so zaposleni imeli štiridnevni delavnik namesto petdnevnega. Izjemno se je povečalo število samomorov, zato so pojav poimenovali »vikend samomor «. Da bi se temu izognili, bi morali razvoj in blaginjo graditi na nematerialnih virih zadovoljstva. Cilj tako zastavljene družbene pragmatike je ustvarjalen človek, plod dobro strukturiranega in humaniziranega izobraževalnega sistema, ki razvija človekove potenciale in krepi njegovo samopodobo. Vzgaja odgovornega posameznika, ki se zaveda svoje vpetosti v družbo in želi vanjo tudi prispevati. Vseživljenjskost učenja mu je nuja, saj želja in potreba po izzivih presega omejenost t. i. večne varnosti. Sproti se sa-

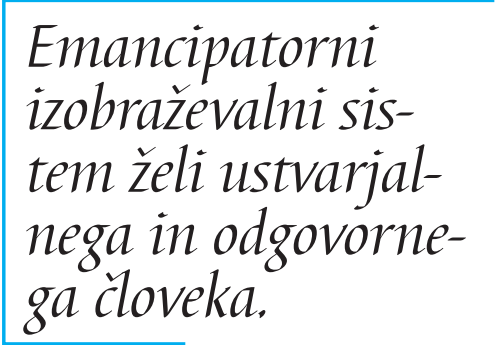
moevalvira na področju pogojev in potencialov lastnega življenja in inovativno rešuje probleme. Kakšna je družbena odgovornost do takega posameznika? Naloga in vloga družbe se kaže prav v emancipatornosti izobraževalnega sistema, ki ima v svoji strukturi in učni strategiji v viziji ustvarjalnega in odgovornega človeka.

»/.../ posamezno življenje je v svoji enkratnosti 'velika dragocenost', vsak 'večni človek' pa 'večni svet'. Ker pa je v vsakem jaznem sebstou posameznika prisoten 'jaz sem tu' tistega 'jaz sem', sta življenje in svet vsakega posameznika tudi ves svet in vse stvarstvo, zajeta v eno. /.../V tem smislu je moja življenjska zgodba življenjska zgodba vsakega človeka, zgodovina človeštva /.../" (Neumann, 2001: 204)

\section{LITERATURA}

Bauman, Z. (2008). Identiteta. Pogovori z Benedettom Vecchijem. Ljubljana: Založba /*cf.

Gardner, H. (1983). Frames of Mind. New York: Basic Books.

Grealy, D. S., Hall-Ellis, S. D. (2009). From Research to Practice. Westport: Libraries Unlimited.

Von Henting, H. (1997). Humana škola. Zagreb: EDUCA.

Honey, P., Mumford, A. (2000). The Learning Styles Helper's Guide. Maidenhead: Peter Honey Publications, Ltd.

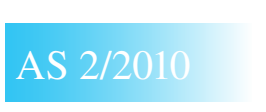


Jelenc, Z. (ur.). (2009). Strategija vseživljenjskosti učenja v Sloveniji. Ljubljana: Ministrstvo za šolstvo in šport RS, Javni zavod Pedagoški inštitut.

Jelenc-Krašovec, S., Jelenc, Z. (2003). Andragoško svetovalno delo. Ljubljana: Filozofska fakulteta Univerze v Ljubljani, Oddelek za pedagogiko in andragogiko.

Juul, J. (2008). Kompetentni otrok. Radovljica: Založba Didakta.

Koestler, A. (1964). The Act of Creation. London: Pan Books.

Krajnc, A. (2010). »Pospešeno in kakovostno izobraževanje odraslih je pot iz gospodarske krize«. Ljubljana. Andragoška spoznanja, 16, 1: 10-22.

-1979. Metode izobraževanja odraslih. Ljubljana: DE.

Lyotard, J. F. (2002). Postmoderno stanje. Ljubljana: Analecta.

Makarovič, J. (2003). Antropologija ustvarjalnosti. Ljubljana: Nova revija.

Neumann, E. (2001). Ustvarjalni človek. Ljubljana: Študentska založba.

Ule, M. (2000). Sodobne identitete v vrtincu diskurzov. Ljubljana: Zbirka Sophia.

- 1992. Socialna psihologija. Ljubljana: Znanstveno in publicistično središče.

- 2009. Socialna psihologija. Analitični pristop $k$ življenju v družbi. Ljubljana: Založba FDV.

Wallerstein, I. (1999). I. Utopistike ali izbira zgodovinskih možnosti 21. stoletja. Ljubljana: Založba /*cf.

- 2000. Kako odpreti družbene vede. Ljubljana: Založba /*cf. 